VIEWPOINT

\section{Chemical pathology and the new contract for GPs}

\section{P J Twomey, A S Wierzbicki, T M Reynolds}

\section{More targets mean more work for the chemical pathology laboratory}

in he new GMS contract agreed in 2003 is arguably the biggest change in terms of service since the formation of the National Health Service. Work practices, and hence surgery income, will be determined by several income streams, one of which is a quality payment for achieving defined clinical goals. ${ }^{1}$ Several of those goals directly or indirectly involve the results of analyses carried out in pathology laboratories, ${ }^{1}$ and accordingly the new contract will potentially have a major impact on the workload within pathology and to varying degrees within subspecialties.

\section{Quality indicator points}

Clinical quality indicators comprise 550 of the 1050 points and 91 directly involve results of tests carried out in chemical pathology (table 1). ${ }^{1}$ Requesting patterns vary from one practice to another ${ }^{2}$ and region to region, and similarly, the availability of tests varies from one laboratory to another. Accordingly, the effect will vary for each laboratory depending on the relative workload from general practice and the current background rate of requesting. Microalbuminuria is one test mentioned in the new GMS contract that fits into this category, with some district hospital laboratories not currently providing this assay on a routine basis.

\section{"The new GMS contract will prob- ably increase the number of disease registers for many general prac- tices"}

In addition to the specific analytes mentioned in table 1 , at least 33 points indirectly involve chemical pathology laboratories (table 2). ${ }^{1}$ The use of angiotensin converting enzyme (ACE) inhibitors and A2 antagonists should result in repeat renal profile requesting in accordance with the British National Formulary advice ${ }^{3}$ for repeat testing after each titration step. Patients with hypertension are often on ACE inhibi- tors or A2 antagonists, and thus should have more frequent requests for renal profiles than similar patients without hypertension. Furthermore, because of their increased vascular risk, these patients are more likely to have full lipid profiles requested, which may be tested more frequently because of the opportunity presented by renal testing. This will probably include the measurement of high density lipoprotein cholesterol, as recommended by the National Service Framework for coronary heart disease in England and Wales, ${ }^{4}$ but not offered by $15 \%$ of laboratories. ${ }^{5}$ The new GMS contract will probably increase the number of disease registers for many general practices. We believe that the mere fact of having more registers and the regular review of patients with diseases that do not specifically involve biochemical analytes, for example epilepsy and cancer, may potentially increase the use of support services such as chemical pathology. Epilepsy registers in particular may result in increased requests for therapeutic drug monitoring. Other potential indirect effects include an increase in the number of requests for creatine kinase and liver function test profiles to monitor for potential side effects, as a result of the increased number of patients on higher doses of statins that will probably occur with the contract.

Each clinical indicator and target has a specific number of points for achieving the associated maximum threshold (tables 1 and 2). Practices will start earning points in the various categories once they achieve the minimum threshold of $25 \%$ and will earn more points up to the respective maximum threshold. However, most general practice managers will probably aim to maximise the number of points. Unless there is a major change in current practice, many of the chronic conditions such as diabetes and hypercholesterolaemia will probably be slowly titrated, with the consequence of multiple tests for each patient. This is especially likely where the maximum threshold is above the median. This is because high risk populations are biased to the right and have higher clinical indicator values relative to a predominantly normal population-for example, those populations that develop coronary heart disease have higher total cholesterol median values than populations that do not develop the disease. ${ }^{6}$ In addition, there is usually a slight skew towards the highest values. These two factors mean that a greater degree of risk factor reduction will be needed to achieve the required population median for the maximum thresholds outlined in the GMS contract.

Work in chemical pathology can be broken down into preanalytical, analytical, and postanalytical phases. Increased general practice requesting will present challenges at all three levels. Information technology (IT) links may play an important part in the preanalytical and the postanalytical phases, with laboratory technology being important for the preanalytical and analytical stages.

\section{Preanalytical phase}

We believe that most primary care requesting is currently via paper request forms, either using stand alone single discipline or multidiscipline forms. Multidiscipline forms are obviously easier for requestors, but the process remains time consuming for both the requestor and the laboratories and is prone to errors. Similarly, it is difficult and time consuming for general practices to document what tests have been requested. The job of inputting data into a laboratory information system is not necessarily rewarding, and many laboratories find it difficult to recruit and retain appropriate staff. Changing to electronic requesting would reduce the number of errors, produce an audit trail, and help to address staffing requirements within laboratories, but would involve substantial investment in IT.

Another preanalytical issue is the frequency of collections from general practice. Most laboratories receive one or two deliveries each day from general practices. Because most laboratories receive a weekday delivery after 16:00 from primary care, an increase in the primary care workload may place a relatively large burden on some laboratories, especially those where general practice represents a large proportion of the total workload. This is especially the case in those laboratories where there may only be a single member of staff working in chemical pathology after the end of the routine working day. More frequent deliveries would help to even out this effect throughout the day, but this may not be practical or cost efficient 
Table 1 Clinical indicators, targets, maximum thresholds, and points for achieving targets that directly affect chemical pathology laboratories

\begin{tabular}{|c|c|c|c|}
\hline $\begin{array}{l}\text { Annex A } \\
\text { code }\end{array}$ & Clinical indicator and target & $\begin{array}{l}\text { Maximum } \\
\text { threshold }\end{array}$ & Points \\
\hline CHD 7 & $\begin{array}{l}\text { The percentage of patients with CHD whose notes have a } \\
\text { record of total cholesterol in the previous } 15 \text { months }\end{array}$ & $90 \%$ & 7 \\
\hline CHD 8 & $\begin{array}{l}\text { The percentage of patients with CHD whose last measured total } \\
\text { cholesterol (measured in the last } 15 \text { months) is } 5 \mathrm{mmol} / \mathrm{l} \text { or less }\end{array}$ & $60 \%$ & 16 \\
\hline Stroke 7 & $\begin{array}{l}\text { The percentage of patients with TIA or stroke who have a } \\
\text { record of total cholesterol in the past } 15 \text { months }\end{array}$ & $90 \%$ & 2 \\
\hline Stroke 8 & $\begin{array}{l}\text { The percentage of patients with TIA or stroke whose last } \\
\text { measured total cholesterol (measured in the past } 15 \text { months) } \\
\text { is } 5 \mathrm{mmol} / \mathrm{l} \text { or less }\end{array}$ & $60 \%$ & 5 \\
\hline DM 5 & $\begin{array}{l}\text { The percentage of patients with diabetes who have a record } \\
\text { of } \mathrm{HbA}_{1 \mathrm{C}} \text { or equivalent in the past } 15 \text { months }\end{array}$ & $90 \%$ & 3 \\
\hline DM 6 & 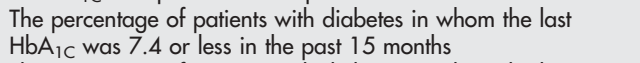 & $50 \%$ & 16 \\
\hline DM 7 & $\begin{array}{l}\text { The percentage of patients with diabetes in whom the last } \\
\mathrm{HbA} A_{1 C} \text { was } 10.0 \text { or less in the past } 15 \text { months }\end{array}$ & $85 \%$ & 11 \\
\hline DM 13 & $\begin{array}{l}\text { The percentage of patients with diabetes who have a record } \\
\text { of microalbuminuria testing in the past } 15 \text { months (exception, } \\
\text { reporting for patients with proteinuria) }\end{array}$ & $90 \%$ & 3 \\
\hline DM 14 & $\begin{array}{l}\text { The percentage of patients with diabetes who have a record } \\
\text { of serum creatinine testing in the past } 15 \text { months }\end{array}$ & $90 \%$ & 3 \\
\hline DM 16 & $\begin{array}{l}\text { The percentage of patients with diabetes who have a record } \\
\text { of total cholesterol in the past } 15 \text { months }\end{array}$ & $90 \%$ & 3 \\
\hline DM 17 & $\begin{array}{l}\text { The percentage of patients with diabetes whose last measured } \\
\text { total cholesterol within the past } 15 \text { months was } 5 \text { or less }\end{array}$ & $60 \%$ & 6 \\
\hline Thyroid 2 & $\begin{array}{l}\text { The percentage of patients with hypothyroidism with thyroid } \\
\text { function tests recorded in the past } 15 \text { months }\end{array}$ & $90 \%$ & 6 \\
\hline MH 3 & $\begin{array}{l}\text { The percentage of patients on lithium treatment with a record } \\
\text { of lithium concentrations checked within the past } 6 \text { months }\end{array}$ & $90 \%$ & 3 \\
\hline MH 4 & $\begin{array}{l}\text { The percentage of patients on lithium treatment with a record } \\
\text { of serum creatinine and TSH in the preceding } 15 \text { months }\end{array}$ & $90 \%$ & 3 \\
\hline MH 5 & $\begin{array}{l}\text { The percentage of patients on lithium treatment with a record } \\
\text { of lithium concentrations in the therapeutic range within the } \\
\text { past } 6 \text { months }\end{array}$ & $70 \%$ & 5 \\
\hline
\end{tabular}

$\mathrm{CHD}$, coronary heart disease; $\mathrm{HbA}_{1 \mathrm{C}}$, glycated haemoglobin; TIA, transient ischaemic attack; TSH, thyroid stimulating hormone. for many laboratories offering a service to rural areas. Irrespective of this, flexible working patterns will be essential to the running of most laboratories. ${ }^{7}$

Although chemical pathology laboratories regularly review new laboratory instrumentation, the new GMS contract is another issue to bear in mind when doing so. Total laboratory automation (or a modular front end automation if total automation is not possible) may be more viable for some laboratories as a result of the increased workload. Not only might this help address preanalytical staffing levels, it may also help to improve turnaround times and reduce errors. ${ }^{8}$

\section{Analytical phase}

Analytical efficiency is improving each year. An increase in workload at the end of the routine working day will mean that higher throughput analysers may be required, although this will partly be
Table 2 Clinical indicators, targets, maximum thresholds, and points for achieving targets that will probably indirectly affect chemical pathology laboratories

\begin{tabular}{|c|c|c|c|}
\hline $\begin{array}{l}\text { Annex A } \\
\text { code }\end{array}$ & Clinical indicator and target & $\begin{array}{l}\text { Maximum } \\
\text { threshold }\end{array}$ & Points \\
\hline CHD 11 & $\begin{array}{l}\text { The percentage of patients with a history of myocardial } \\
\text { infarction (diagnosed after } 1 \text { April 2003) who are currently } \\
\text { treated with an ACE inhibitor }\end{array}$ & $70 \%$ & 7 \\
\hline LVD 3 & $\begin{array}{l}\text { The percentage of patients with a diagnosis of } \mathrm{CHD} \text { and left } \\
\text { ventricular dysfunction who are currently treated with } \mathrm{ACE} \\
\text { inhibitors (or } \mathrm{A} 2 \text { antagonists) }\end{array}$ & $70 \%$ & 10 \\
\hline BP 1 & $\begin{array}{l}\text { The practice can produce a register of patients with established } \\
\text { hypertension }\end{array}$ & & 9 \\
\hline DM 15 & $\begin{array}{l}\text { The percentage of patients with diabetes with proteinuria or } \\
\text { microalbuminuria who are treated with ACE inhibitors (or A2 } \\
\text { antagonists) }\end{array}$ & $70 \%$ & 3 \\
\hline Epilepsy 3 & $\begin{array}{l}\text { The percentage of patients aged } 16 \text { and over on drug } \\
\text { treatment for epilepsy who have a record of medication review } \\
\text { in the previous } 15 \text { months }\end{array}$ & $90 \%$ & 4 \\
\hline
\end{tabular}

dependent on the postanalytical arrangements. A related issue is the greater need for user friendly analytical platforms: a large linear range to reduce the number of dilutions, automated dilutions, clot and short sample detectors, serum indices that are not time consuming or require large samples, etc. More and more immunoassay assays are being added to routine chemistry analysers, which should improve sample handing efficiency. However, in the absence of total laboratory automation, a tracking system between the routine chemistry analyser and the main dedicated immunoassay analyser may be advantageous.

\section{Postanalytical phase}

Links between laboratory information systems and general practice IT systems may also play an important role in the implementation of the new GMS contract. All the direct points involving chemical pathology (table 1) depend on the recording within primary care of specific results. The lack of a result in a patient record, irrespective of whether an analyte has been analysed or not within the required time span, might prompt a repeat request. Lack of patient compliance for phlebotomy and medication will be recorded. This is to ensure that those who serially fail to comply are excluded from the calculations for the award of points. The obvious model for such a system is the call/recall systems used in cervical screening services. Irrespective of compliance, it will be in the interest of practices to ensure that as many patients as possible have the required tests before the end of the required time span. Accordingly, systems that invite the patient well in advance of the required time span will probably be developed, resulting in even more frequent testing.

\section{"Links between laboratory informa- tion systems and general practice information technology systems may also play an important role in the implementation of the new GMS contract"}

Another issue that is unclear is whether and how patient results from secondary care are transferred to primary care. Electronic transfer from a laboratory information system based on a patient specific identifier to primary care, irrespective of whether the general practitioner was the requester or not, may result in a smaller increase in requesting from primary care. However, general practitioner messaging systems have been on the horizon for more than 10 years, and problems still occur because of the disparate software 
used by general practitioner surgeries and pathology laboratories. Further problems arise from the issues of encryption of personal information, and transfer by email of many results (or their interpretation) may not conform with the Data Protection Act. ${ }^{9}$

A topical and important issue is the reporting of grossly abnormal results that arise outside usual general practitioner surgery hours: currently, the Royal College of Pathologists is liaising with the Royal College of General Practitioners with a view to clarifying the responsibilities of the various people involved..$^{10}$ An increase in the number of requests will probably give rise to a greater number of abnormal results compared with the current level, and this is even more likely if the requests are for high risk patients. Currently, postanalytical result reporting varies from one laboratory to another. Many district general hospitals have single handed consultants, and some believe that this may make them less flexible with respect to the reporting of results after 17:00 when compared with university hospitals, which traditionally have higher staffing levels. However, single handed operators may not use complex duty biochemist structures to "authorise" clinically abnormal results, so result transfer to general practitioners may be easier. Similarly, some general practitioner out of hours arrangements place general practitioners in district general hospital casualty units, which greatly facilitates transfer of abnormal reports. However, it is expected that many general practitioners will opt out of the out of hours service (after 18:30) and the primary care organisations will provide this service; therefore, it is not clear whether the integration of general practitioner night cover and laboratories will improve or degrade. Accordingly, a protocol will need to be agreed with both general practices and primary care organisations for the handling of abnormal patient results during out of hours periods and the following working day.

Most chemical pathology laboratories are currently understaffed. ${ }^{11}$ An increase in general practitioner requesting will probably be associated with an increased requirement for clinical liaison, clinical advice, and clinical audit. Accordingly, there will probably be an increased demand on an already stretched service. ${ }^{11}$ Patients who are not reaching the various clinical targets outlined in Annex A will probably be referred to specialist clinics, such as lipid and vascular risk clinics. Thus, chemical pathologists may face an increased demand both within and outside of the laboratory. Furthermore, the complexity

of the patients referred is likely to change with an increase in referral of those patients in whom it is not clear that cholesterol lowering is essential. Borderline patients often require multiple testing to identify on which side of the risk divide they fall. Consequently, changes in lipid clinic case mix will also probably have an effect.

\section{Point of care testing}

Although this article has concentrated on the effect of the GMS contract on traditional centralised laboratories, large primary care practices may have an increased incentive to move much more work in house by using point of care test (POCT) analysis. Already many systems exist for the measurement of glucose, glycated haemoglobin, and increasingly lipids with an allied liver function test (alanine transaminase) and glucose. Semiquantitative dipstick strips are available for microalbuminuria. Under clinical governance regulations, all POCT analysers have to use internal quality control and participate in external quality assurance schemes, ${ }^{12}$ and there must be acceptable comparability to the centralised laboratory method. The executive summary of this document clearly ${ }^{12}$ states "the need for local hospital pathology laboratory involvement in all aspects of a POCT service". Thus, the workload for laboratories will increase because many of these systems rely on local centres to provide reference materials and manage details of the local internal quality control, external quality assurance, training, and accreditation.

\begin{abstract}
"Any increased requesting will have financial implications for chemical pathology laboratories and it is not clear where this extra funding will come from"
\end{abstract}

\section{CONCLUSION}

Annex $\mathrm{A}^{1}$ outlines the clinical indicators of the new GMS contract. Of all the laboratories, chemical pathology will probably have a large increase in workload as a result of the new GMS contract. This will vary from one laboratory to another and have important consequences on staffing levels, instrumentation, and the financial requirements involved. Any increased requesting will have financial implications for chemical pathology laboratories and it is not clear where this extra funding will come from.

It is in the interest of chemical pathology laboratories to ensure that excellent IT links exist between labora- tory information system and general practitioner IT systems. The use of laboratory technological advances is also more likely to play a part in the adaptation to the new order within the National Health Service. However, technological advances also cost money and, as with the increased requesting, it is not clear whether extra money will be available to pay for this, especially because some see laboratories as already being "awash with modern IT systems". ${ }^{13}$

J Clin Pathol 2004;57:1022-1024.

doi: 10.1136/icp.2003.015016

\section{Authors' affiliations}

P J Twomey, Department of Clinical Biochemistry, Little France Crescent, Edinburgh EHI 6 4SA, UK

A S Wierzbicki, St Thomas' Hospital, Lambeth Palace Rd, London SEI 7EH, UK

T M Reynolds, Queen's Hospital, Belvedere Road, Burton on Trent, Staffordshire DE13 $O R B, U K$

Correspondence to: Dr P J Twomey, Department of Clinical Biochemistry, Edinburgh Royal Infirmary, Little France Crescent, Edinburgh EH16 4SA, UK; Taptwomey@aol. com

\section{REFERENCES} http://www.bma.org/ap.nsf/Content/ NewGMSContract/\$file/gpcontractannexa.pdf (last accessed 15 November 2003).

2 Smellie WSA, Galloway MJ, Chinn D. Is clinical practice variability the major reason for differences in pathology requesting patterns in general practice? J Clin Pathol 2002;55:312-14.

3 British National Formulary 43, March 2002, page 91. London: The British Medical Association and the Royal Pharmaceutical Society of Great Britain, ISBN 0-85369-510-5.

4 http://www.doh.gov.uk/nsf/coronary.htm (last accessed 24 November 2003)

5 Hutchesson ACJ, O'Kane MJ, Neely RD, et al. Availability and reporting of lipid analyses: a national audit. Abstracts of 18th HEART UK meeting, Bath. Atherosclerosis (In press.)

6 Castelli WP. Cholesterol and lipids in the risk of coronary artery disease - the Framingham hear study. Can J Cardiol 1988:4(suppl A):5A-10A

7 Agenda for change. http://www.doh.gov.uk/ agendaforchange/ (last accessed 20 November 2003).

8 Graves S, Holman B, Felder RA. Modular robotic workcell for coagulation analysis. Clin Chem 2000;46:772-7.

9 Gordon C, Krimholtz M. E-mail and patients: a medicolegal minefield. Lancet 2003;362:1768.

10 Freedman DB. College council: 8 May 2003. The Bulletin of the Royal College of Pathologists 2003; 123:9-12.

11 NHS Clinical Biochemistry "A profession under siege". http://www.rcpath.org/resources/pdf/ a_prof_under_seige.pdf (last accessed 20 November 2003).

12 http://www.medical-devices.gov.uk/mda/ mdawebsitev2.nsf/ e8be0ee313c493aa80256bbb00307b2e/ 5a056c9be12, aff7fc680256c8b00565ad3/ \$FILE/db2002(03).pdf (last accessed 24 November 2003).

13 Jones R. Harnessing technology to modernise service delivery: electronic pathology messaging in the NHS. The Bulletin of the Royal College of Pathologists 2003;122:20-4. 